\title{
PERSONALISED FORMWORK - scientific approach for new solution variants
}

\author{
Raluca Diaconu ${ }^{1 *}$, and Paul Dan Brindasu ${ }^{1}$ \\ ${ }^{1}$ University "Lucian Blaga" of Sibiu, Faculty of Engineering, Emil Cioran 4, Sibiu, Romania
}

\begin{abstract}
Application of personalised formwork is of most interest for architects and engineers now-a-days. Although a required demand when designing special constructions, there is little data and material solutions for this case. The cost and domain of application are of most importance in determining new solutions for concrete formworks. To contribute to these requests (a wider usage domain, productive material cost and maintenance), a personalised formwork concept is presented. The idea of reusing the formwork led to an elastic material - membrane (thermoset elastomers, synthetic rubber) with a punching tie-rod solution in order to obtain any architectural shape desired. This first solution was evaluated taking into account different membrane thicknesses. Several experimental tests denoted that the named chosen membrane variants are of low resistance for pouring a concrete architectural slab, so new solutions were discussed. Hence, a re-analysis of the PLM steps was achieved in order to find an answer for the encountered problem. By using creative methods, we obtained a second solution and put it to test. The attained results are used in order to establish the area of workability, to enlarge the tested domain and to assess the sustainability of a new type of personalised formwork
\end{abstract}

\section{Introduction}

The now-a-days architectural demands require new formwork solutions for concrete free shape structural elements. The need for special shapes was put to test in the early ' 40 s (Fig. 1), but still, the current technical solutions for creating such concrete elements are limited and expensive. Hence, a solution is required for these types of structures.

The article discusses different equipment variants that can be reused as formwork and can satisfy different architectural shape. The first tested equipment is composed of pistons that act upon a membrane. Tests showed that this solution is limited: the membrane does not resist to concrete unless the piston density is increased, making this solution inconsistent for large dimensions. A thorough investigation on this formwork variant problem was carried out.

The article focuses on the PLM approach in order to obtain a new second solution for the demands.

\footnotetext{
*Corresponding author: raluca.diaconu@ulbsibiu.ro
} 
We will establish the functions that such equipment must satisfy, followed by technical solutions specification and finally certify through tests the attained new solution.

We conclude the article by evaluating the results in order establish the area of workability, to enlarge the tested domain and to assess the sustainability of the new equipment solution for a personalised formwork.

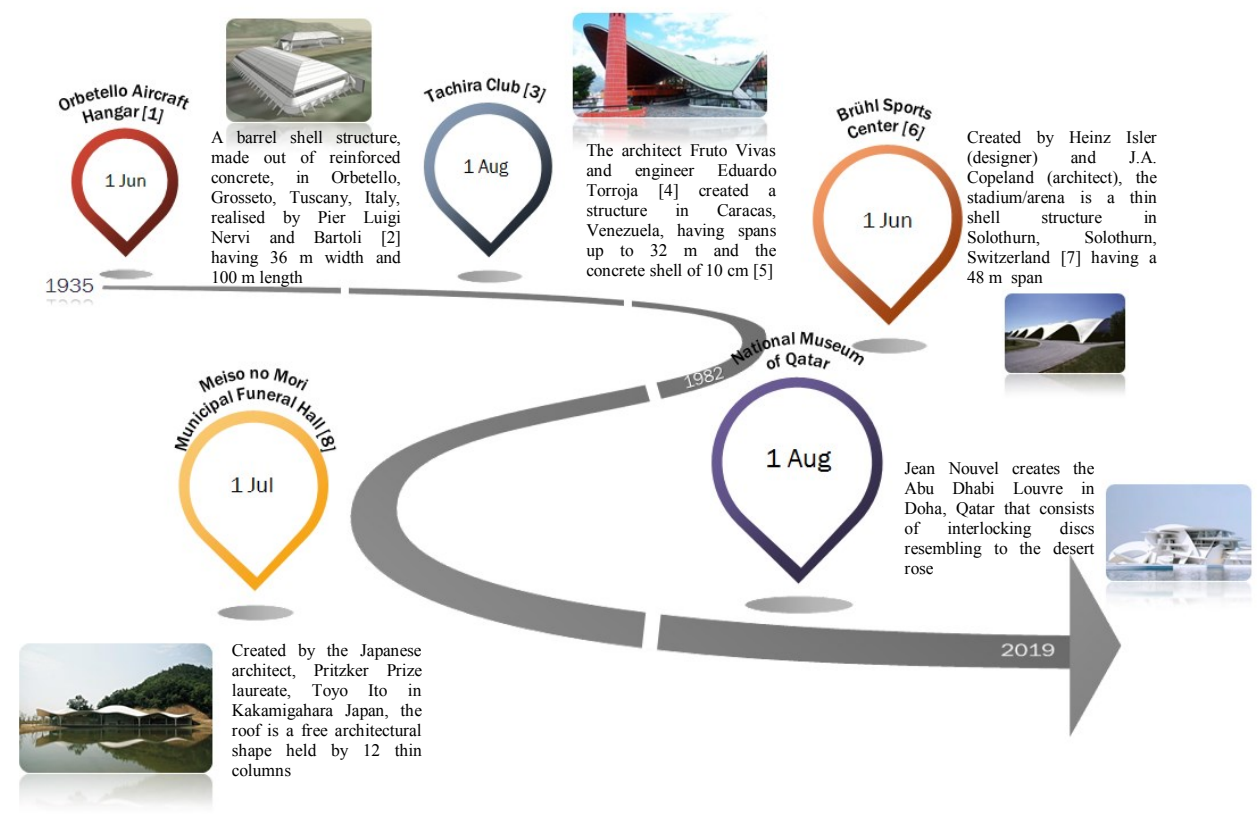

Fig. 1. Free architectural shapes - its beginnings and tendency

\section{State of the art}

After a reminder of the free architectural shapes, an analysis regarding the multitude of shapes encountered in those 3D structural elements was detailed (Fig. 2).

Knowing all these possible patterns, one can see the necessity of a personalised formwork type that can satisfy all of the above described shell types and the possible variants that each shape can led to.

During the years, the idea of creating a formwork for such shapes has fallen, in the last few decades, into place.

Besides the step by step assembly of traditional timber or steel formwork (Poggeler [16]), CNC milling solutions were used (Kolarevic [17]), fabric formwork or even 3D printing solutions.

From these appeared researches in order to simplify or to re-use the formwork: Troian et al.- the use of a deformation MDF base surface and an upper foam/silicone mould [18], Schipper et al.- prototype with two directional actuators acting upon a membrane [19], Beton Ballon [20] - inflatable mould, Boers [21] - pin-bed surface, van Rooy et al. tensioned membrane mould [22] or vacuumatics solutions - Hulijben [23].

But when large scale elements such as roofs/ slabs are involved, the usage of such solution is not optimum neither from the material consumption point of view, assembly or cost. 


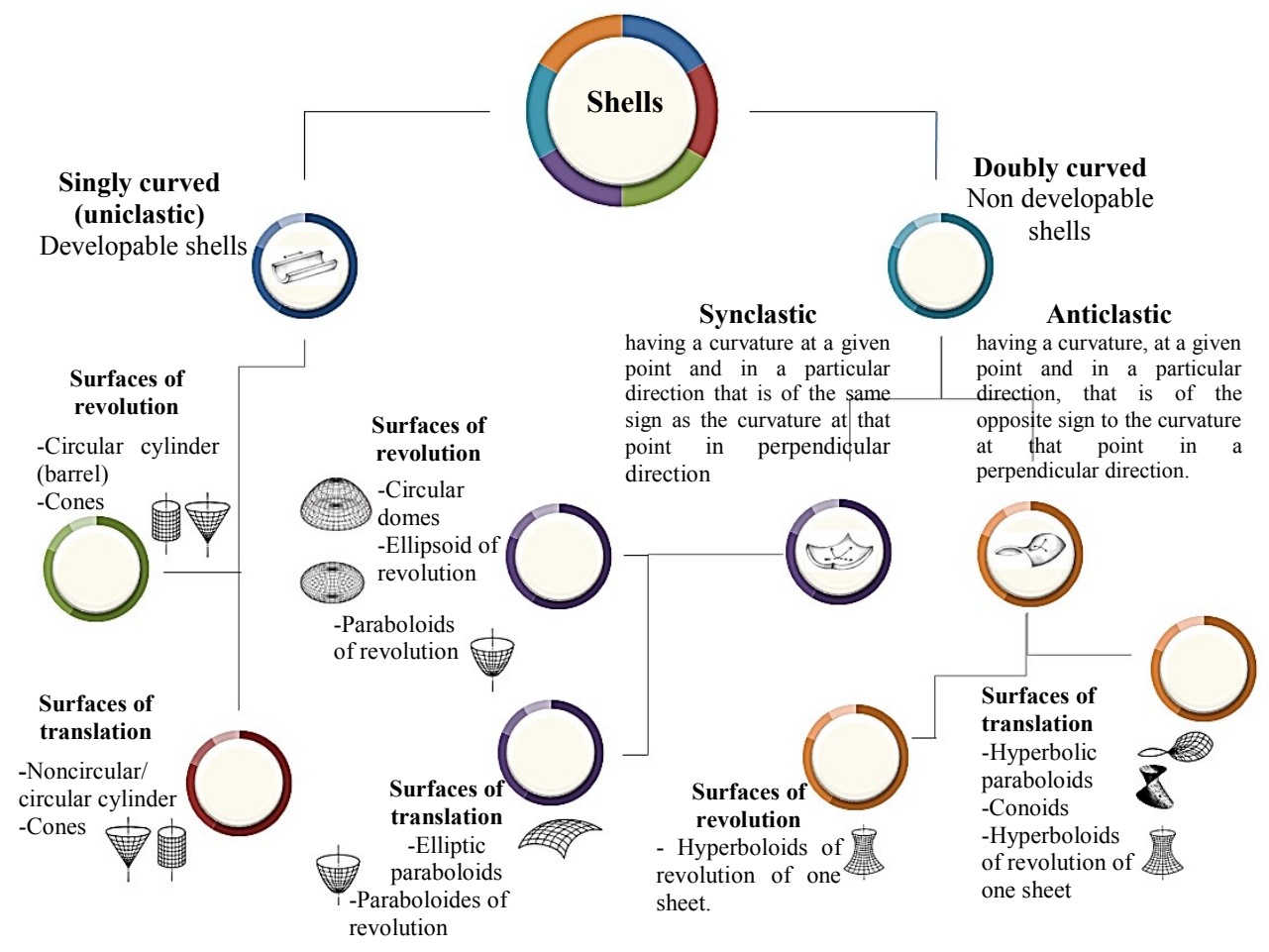

Fig. 2. Affinity diagram regarding structural shell types [11- 14]

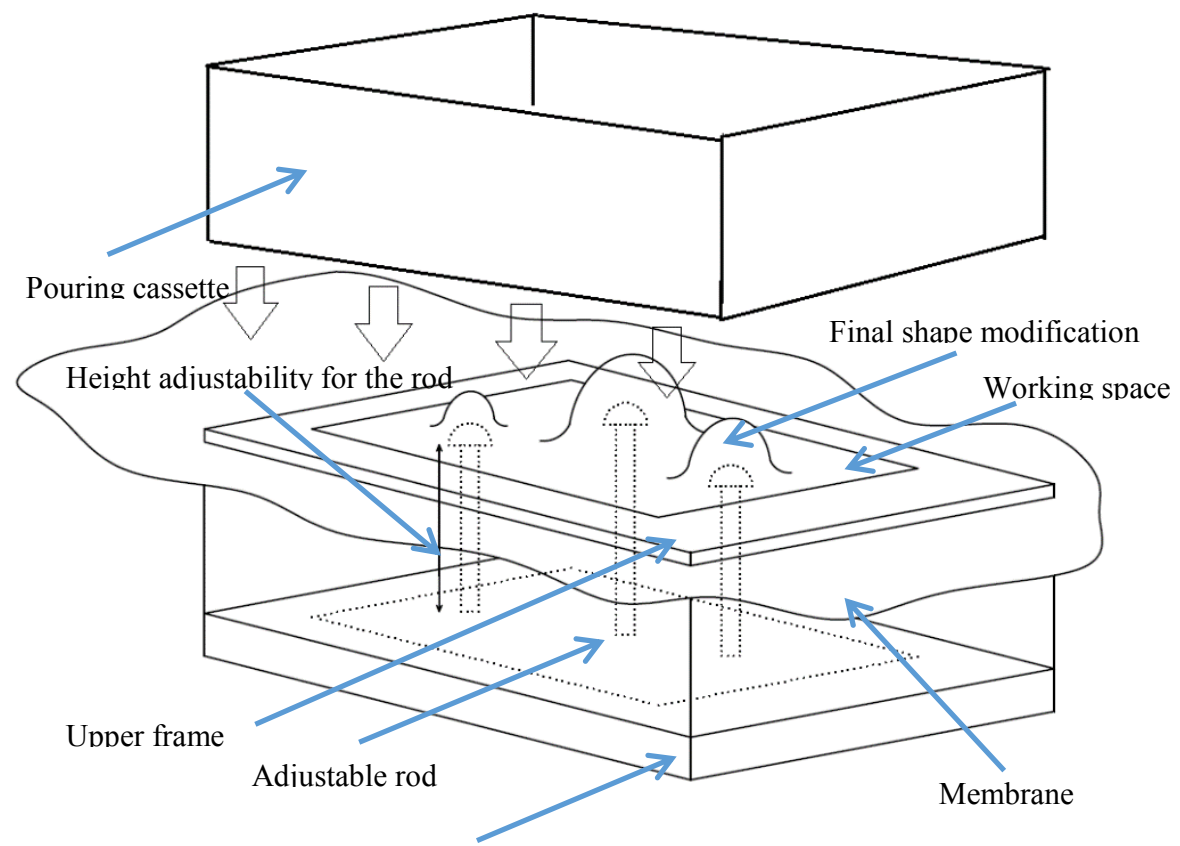

Base frame

Fig. 3. Solution sketch for the tested variant 
In our research (including this article) we try to find an answer for this situation by using a scientific approach.

Hence, multiple solutions for a personalised formwork were analysed. Previous experimental research [15] resulted in various equipment solutions.

Among them is the one represented bellow (Fig. 3): a personalised formwork composed of an elastic material - membrane (thermoset elastomers and synthetic rubber) and a series of punching tie-rods for curvature definition and support.

After several experimental tests, the solution proved to be invalid. At difference levels bigger than $230 \mathrm{~mm}$, after the complex surface is attained, at concrete loading, excess deformations appear that chances the surface characteristics (note: a SBR rubber of $2 \mathrm{~mm}$ thickness was used and a single support rod - Fig. 4).
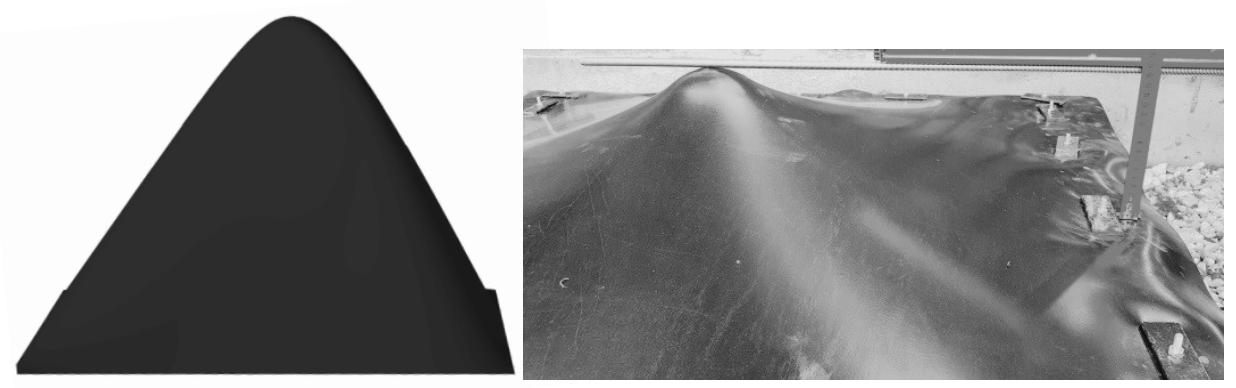

Membrane modification shape according to a) 3D model b) experimental test

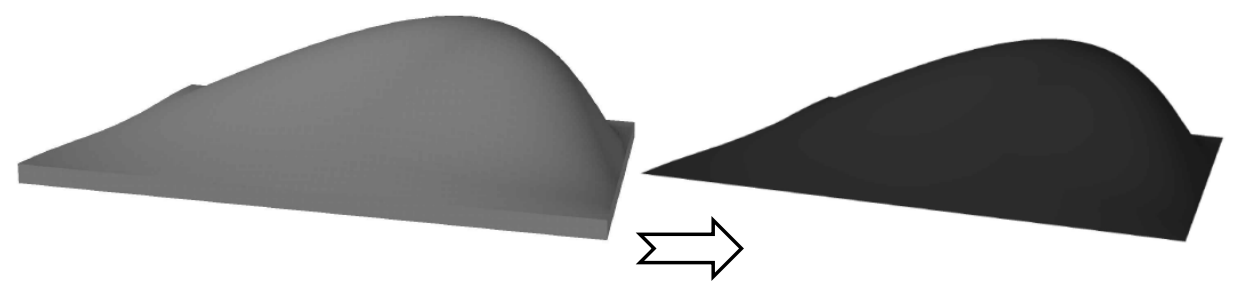

Concrete final shape after membrane deformation (lack of rod)

Membrane final shape 3D view

Fig. 4. Tests results for first variant solution - membrane failure deformation
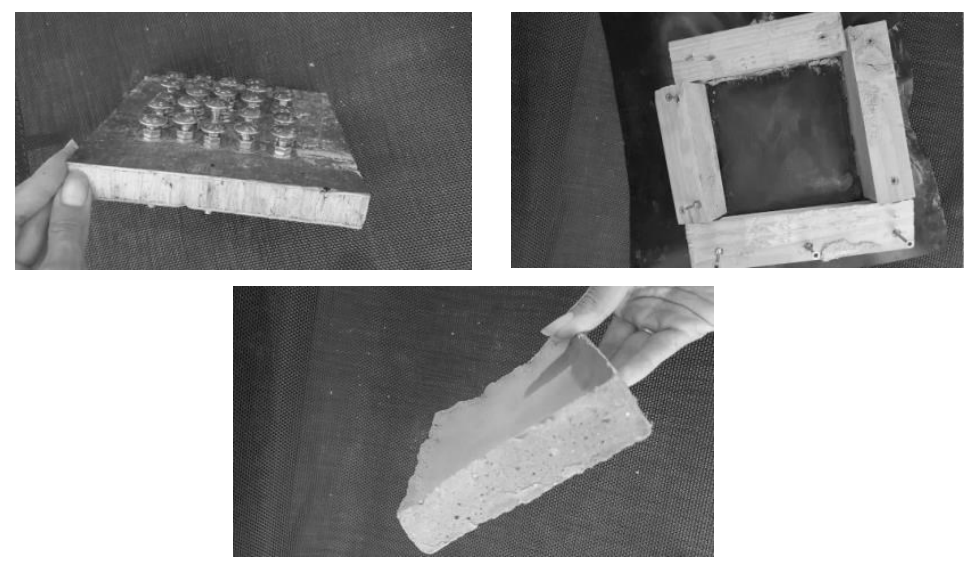

Fig. 5. Tests results when enlarging the piston density - membrane maintains shape 
Although the shape preserves, when changing the piston density on the membrane (Fig. 5), this first solution equipment is ranged as inconsistent for large dimensions.

As a consequence, a thorough analysis, by using the PLM approach is necessary because it allows even in the solution design stage to satisfy the new functions obtained from the invalid tested variant (e.g. maintaining the deformed surface unchanged after concrete pouring) (Fig. 6).

\section{DESIGN}

The design stage contains several steps: Function definition

Function ranking and selection Solution possibilities Optimum solution selection Solution validation and implementation.

\section{USAGE \& MAINTENANCE}

After the market launch, the product must be permanently observed and monitored. Also the periodically evaluations can be made in order to see the efficiency and line up to the constant evolution of the technology.

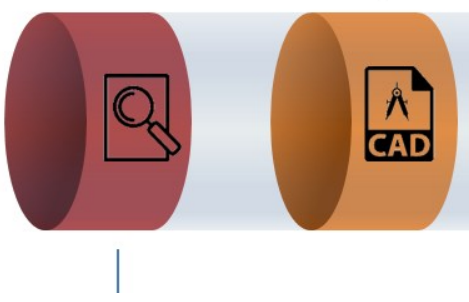

DEMANDS

The market analysis is one of the most important aspects because from here one can determine the requirements for a new solution.

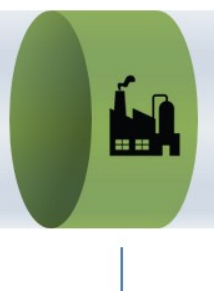

PRODUCTION

The fabrication process includes an economically pre-analysis to see the costs involved in the production.

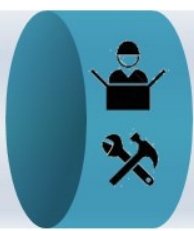

RECYCLING \& END OF

LIFE

Before the retirement phase, the product (or some parts) can be recycled and reintroduced in the loop.

Fig. 6. Product Lifecycle Management steps

\section{PLM approach}

\subsection{Function analysis}

As noted, in the figure above, one of the PLM steps in obtaining an optimum solution for a personalised product is the demands and their analysis.

Because the experimental tests done on the equipment were invalid, the next step was to establish the reason for the test failure, finding a solution for the encountered problem and then determining the resulting requirements. Step two was defining their corresponding functions by using creative methods. Because most of them were complex ones, other focus sessions were made in order to obtain the basic (primary) ones (Table 1).

Another statement referring to the equipment's functions is that, because on the previous tests no other problems were encountered, the elaborate explored demands were the ones concerning shape moulding and fixing: formwork material types, obtaining methods for deformation, blockage and fall-back.

For the other ones, named also annex functions, intuitive or experimental based solutions were adopted.

Also, for this case study no reinforcement for the concrete element was considered. Future analysis will show the steel mounting approach and concrete depth assurance solutions. 
Table 1. Function definition and dividing

\begin{tabular}{|c|c|c|}
\hline Demand & Obtained function & Primary function dividing \\
\hline \multirow{3}{*}{ obtaining shape diversity } & \multirow{3}{*}{ to encase diverse surfaces } & $\begin{array}{c}\text { to obtain complex surfaces } \\
\text { on } \mathrm{x}, \mathrm{y}, \mathrm{z} \text { directions }\end{array}$ \\
\hline & & $\begin{array}{l}\text { to pour a constant concrete } \\
\text { layer according to shape }\end{array}$ \\
\hline & & $\begin{array}{l}\text { to enclose the poured } \\
\text { concrete }\end{array}$ \\
\hline \multirow{2}{*}{ blockage shape system } & \multirow{2}{*}{$\begin{array}{l}\text { to maintain position of the } \\
\text { formwork }\end{array}$} & to fix formwork \\
\hline & & to block system \\
\hline \multirow{3}{*}{ formwork dismantling } & \multirow{3}{*}{ to strike formwork } & to unblock system \\
\hline & & to remove fixing elements \\
\hline & & to remove mould \\
\hline formwork resistance & to resist & to assure formwork strength \\
\hline \multirow{2}{*}{$\begin{array}{l}\text { assuring reinforcement } \\
\text { positioning }\end{array}$} & \multirow{2}{*}{$\begin{array}{l}\text { to mount steel } \\
\text { reinforcement }\end{array}$} & to introduce bars \\
\hline & & $\begin{array}{c}\text { to maintain optimum } \\
\text { distance }\end{array}$ \\
\hline \multirow{3}{*}{$\begin{array}{l}\text { formwork monitoring for crack, } \\
\text { leaks, failure and temperature }\end{array}$} & \multirow{3}{*}{ to control } & to verify formwork state \\
\hline & & to verify formwork position \\
\hline & & to measure temperature \\
\hline $\begin{array}{l}\text { assuring air removal from } \\
\text { concrete }\end{array}$ & $\begin{array}{l}\text { to diminish internal } \\
\text { friction between particles }\end{array}$ & to vibrate concrete \\
\hline $\begin{array}{c}\text { ensuring manoeuvrability and } \\
\text { easy mounting }\end{array}$ & to be handy & to assure moving \\
\hline
\end{tabular}

For these functions, in order to obtain new ideas, brainstorming sessions were formed. Building on the ideas of others or on previous solutions was a plus.

As previously mentioned, for the annex functions, the solutions assigned were based on intuition and test results (Fig. 7).

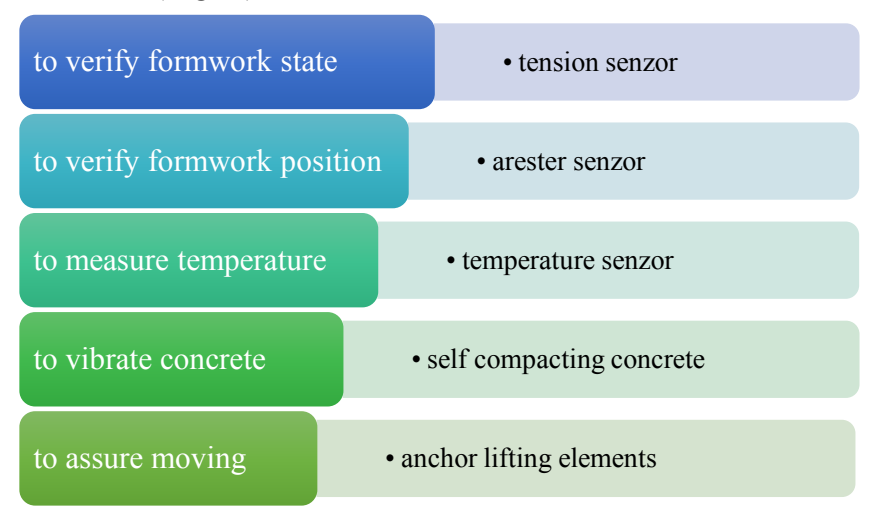

Fig. 7. Function solutions - annex function 
The table below (Table 2) is a representation of the found solutions for each primary function regarding shape assurance.

Table 2. Functions' solution chart

\begin{tabular}{|c|c|c|}
\hline $\begin{array}{l}\text { Primary } \\
\text { function }\end{array}$ & Possible assigned theoretical solution & Assigned technical solution \\
\hline \multirow{7}{*}{$\begin{array}{c}\text { to obtain } \\
\text { complex } \\
\text { surfaces on } \mathrm{x} \text {, } \\
\mathrm{y}, \mathrm{z} \text { directions } \\
\quad-\mathrm{F} 1\end{array}$} & \multirow{3}{*}{ by pushing an elastic mould/ clay } & $\begin{array}{l}\text { umbrella type piston for different } \\
\text { radius shapes and joint hinge }\end{array}$ \\
\hline & & point system formation \\
\hline & & elastic tubular element \\
\hline & by using pressure - shape formation & liquid/gas column pressure \\
\hline & by pulling an elastic mould/ clay & point system pulling \\
\hline & $\begin{array}{l}\text { by cutting / removing parts from a } \\
\text { material }\end{array}$ & clay modelling \\
\hline & by adding parts to a material & spline interpolation forming \\
\hline \multirow{3}{*}{$\begin{array}{c}\text { to pour a } \\
\text { constant } \\
\text { concrete layer } \\
\text { according to } \\
\text { shape - F2 }\end{array}$} & pouring a quick setting material & $\begin{array}{l}\text { pouring a quick time hardening } \\
\text { concrete }\end{array}$ \\
\hline & using double wall formwork & $\begin{array}{l}\text { forming a symmetrical/ mirror } \\
\text { formwork }\end{array}$ \\
\hline & $\begin{array}{l}\text { using an auxiliary pouring element with } \\
\text { the exact thickness dimensions }\end{array}$ & $\begin{array}{l}\text { horizontal personalised pouring } \\
\text { machine }\end{array}$ \\
\hline \multirow{3}{*}{$\begin{array}{l}\text { to enclose the } \\
\text { poured } \\
\text { concrete-F3 }\end{array}$} & securing all margins together & use of a cassette \\
\hline & securing separately each margin & using separate lateral secure sheet \\
\hline & rise the formwork & $\begin{array}{l}\text { establish end point and extend the } \\
\text { extremities of the formwork } \\
\text { (elastic/ clay) }\end{array}$ \\
\hline \multirow{6}{*}{$\begin{array}{c}\text { to fix \& } \\
\text { remove } \\
\text { formwork - } \\
\text { F4 }\end{array}$} & \multirow{3}{*}{ fixing/remove elements under formwork } & $\begin{array}{l}\text { shape forming element with double } \\
\text { role: shape formation and fixing }\end{array}$ \\
\hline & & base material as support \\
\hline & & $\begin{array}{l}\text { wire/ lamella base support that } \\
\text { respects the formwork shape }\end{array}$ \\
\hline & $\begin{array}{l}\text { fixing element in the concrete with } \\
\text { recovery and remove all parts }\end{array}$ & telescopic pipe system \\
\hline & \multirow{2}{*}{$\begin{array}{l}\text { fixing element in the concrete without } \\
\text { recovery but removal of the auxiliary parts }\end{array}$} & $\begin{array}{l}\text { wire/ lamella through pipe system } \\
\text { that respects the formwork shape }\end{array}$ \\
\hline & & tension wire in the concrete \\
\hline $\begin{array}{c}\text { to block/ } \\
\text { unblock } \\
\text { system - F5 }\end{array}$ & $\begin{array}{l}\text { block/ unblock all fixing elements } \\
\text { separately }\end{array}$ & $\begin{array}{l}\text { - for pistons, point system, } \\
\text { point pulling, elastic tube, spline } \\
\text { interpolation and telescopic pipe } \\
\text { system: with clamps, screws, latch, } \\
\text { hydraulic, pneumatic systems } \\
\text { - for clay modelling and base } \\
\text { material support: air removal, entire } \\
\text { necessary clay volume occupied } \\
\text { - for wire/ lamella (exterior } \\
\text { and interior): tension, clips }\end{array}$ \\
\hline
\end{tabular}




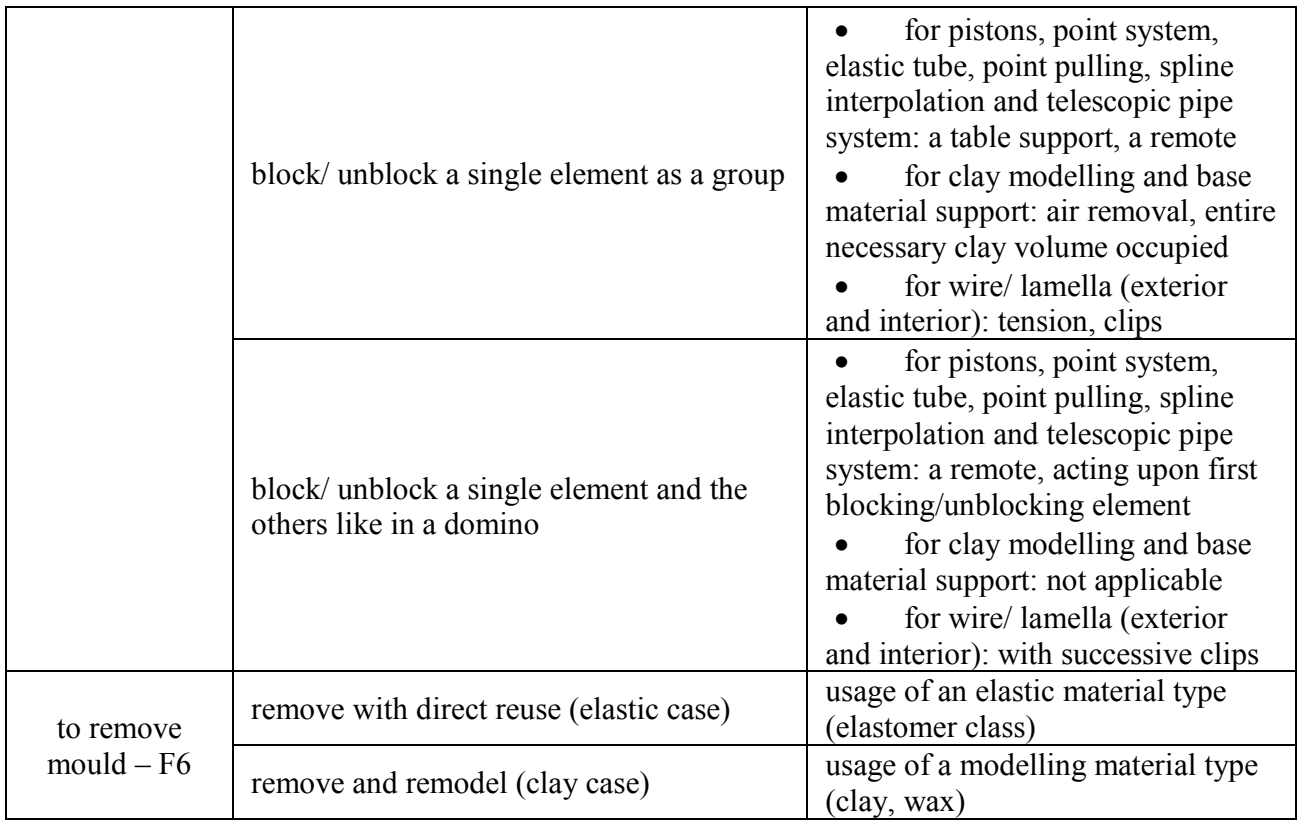

The next step in the PLM analysis is the evaluation of the solutions. Hence, each technical solution was analysed to determine the best one taking into account different criteria. For this case, the QFD matrix was used (Fig.8a,b).

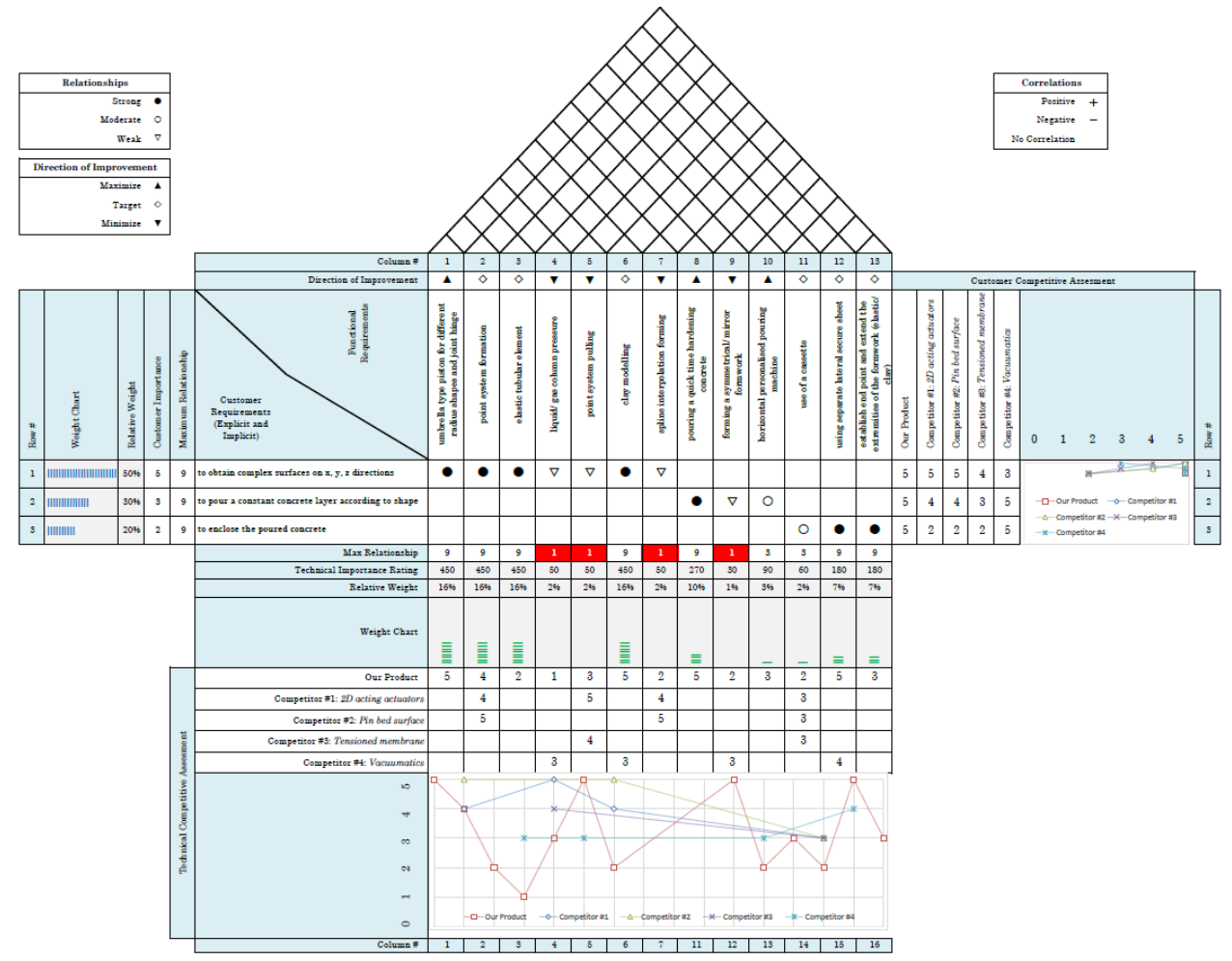

Fig. 8a. QFD matrix for solution evaluation (first three functions) 


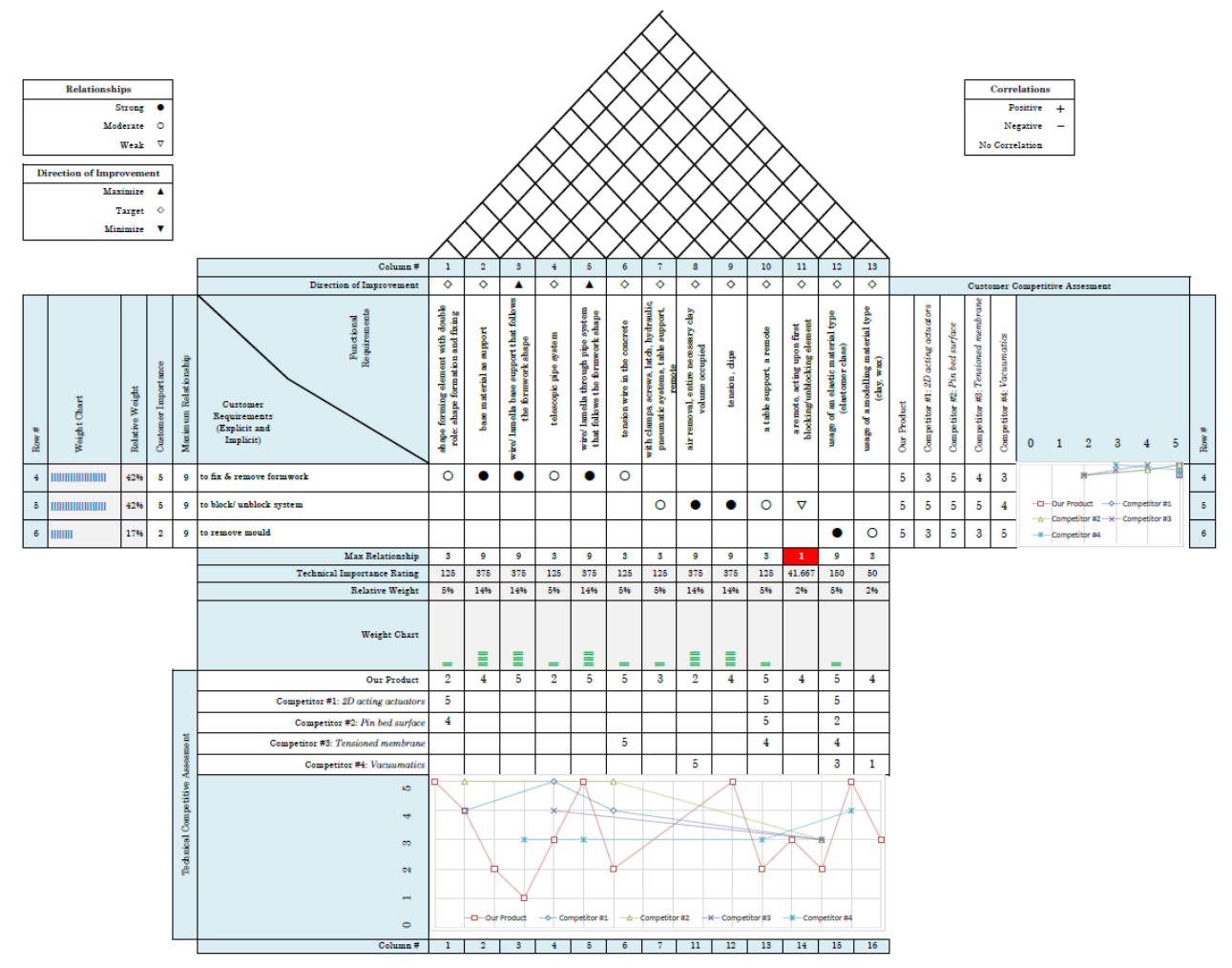

Fig. 8b. QFD matrix for solution evaluation (last three functions)

\subsection{Possible solution}

After a thorough analysis of all the possible solutions regarding the optimisation aspect, efficiency and costs, the possible was adopted solution and will be put up to tests. The morphological matrix shows in a suggestive manner the chosen variant (Fig. 8). Each solution was named as Solution 1-7 for each of the functions F1-6.

Table 2. Morphological matrix

\begin{tabular}{|c|c|c|c|c|c|c|c|}
\hline Function & $\begin{array}{c}\text { Solution } \\
\mathbf{1}\end{array}$ & $\begin{array}{c}\text { Solution } \\
\mathbf{2}\end{array}$ & $\begin{array}{c}\text { Solution } \\
\mathbf{3}\end{array}$ & $\begin{array}{c}\text { Solution } \\
\mathbf{4}\end{array}$ & $\begin{array}{c}\text { Solution } \\
\mathbf{5}\end{array}$ & $\begin{array}{c}\text { Solution } \\
\mathbf{6}\end{array}$ & $\begin{array}{c}\text { Solution } \\
\mathbf{7}\end{array}$ \\
\hline F1 & & & & & & & \\
\hline F2 & & & & & & & \\
\hline
\end{tabular}




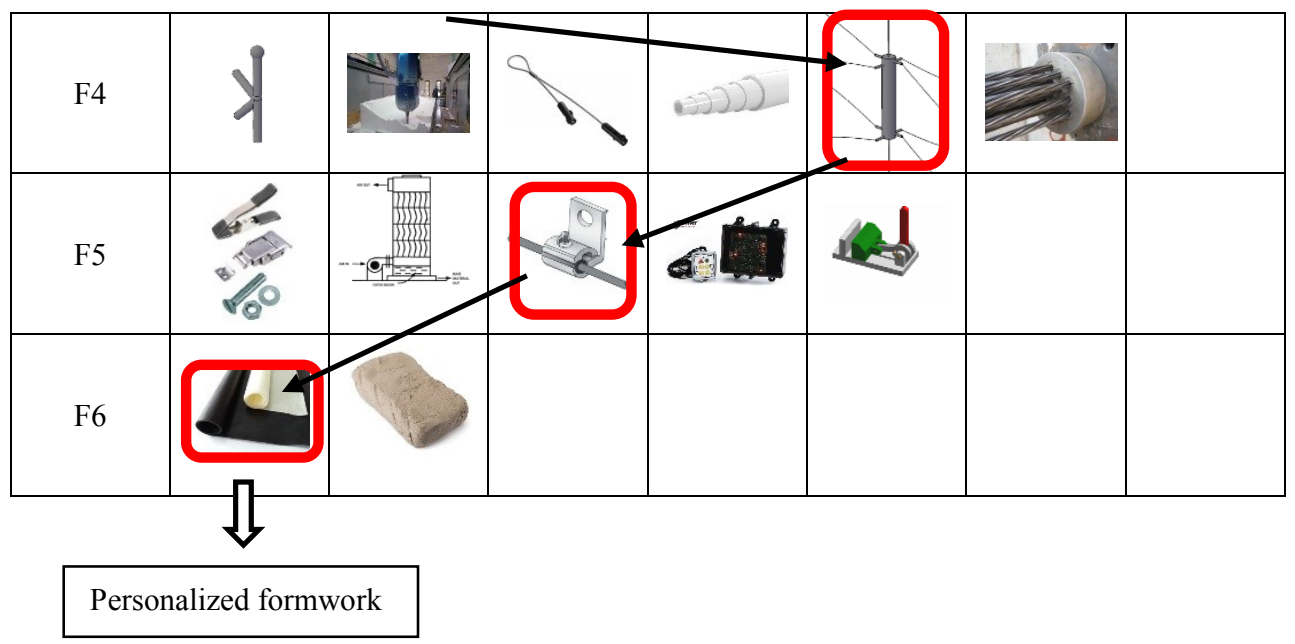

As shown above, the personalised formwork is composed of an elastomeric material with cable pulling solution for shape formation and a spacer rod for thickness assurance. The wires assure the fixing of the membrane. Also, in the spacer, two perpendicular pipes are envisioned in order to strengthen the material. A section through the personalised formwork may clarify the resulting solution (Fig. 9).

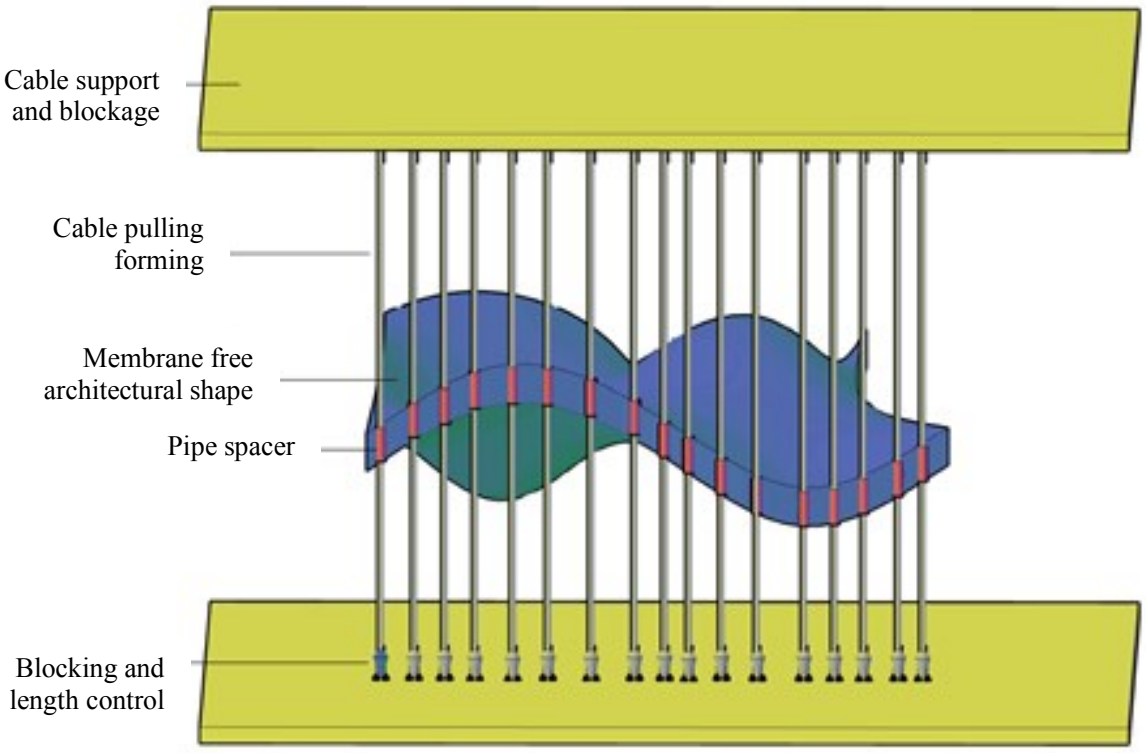

Fig. 9. Personalised formwork section

The next step in the PLM approach is to verify the solution by using F.E.M analysis and experimental testing. 


\subsection{Experimental testing}

Because the solution needs to be validated, an experimental test must be conducted. For this step, the working stages were kept in mind in order to cover all the aspects within a pouring process (Fig. 10).

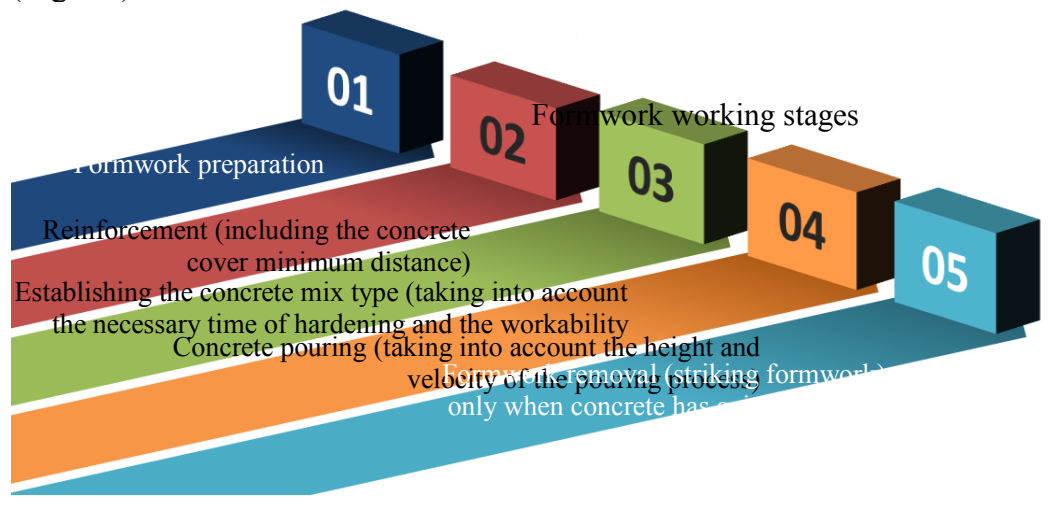

Fig. 10. Working stages for executing a structural element

Taking these steps into account, a virtual testing line for free architectural shape elements was featured (Fig. 11). The new solution for the personalised formwork is then put to test.

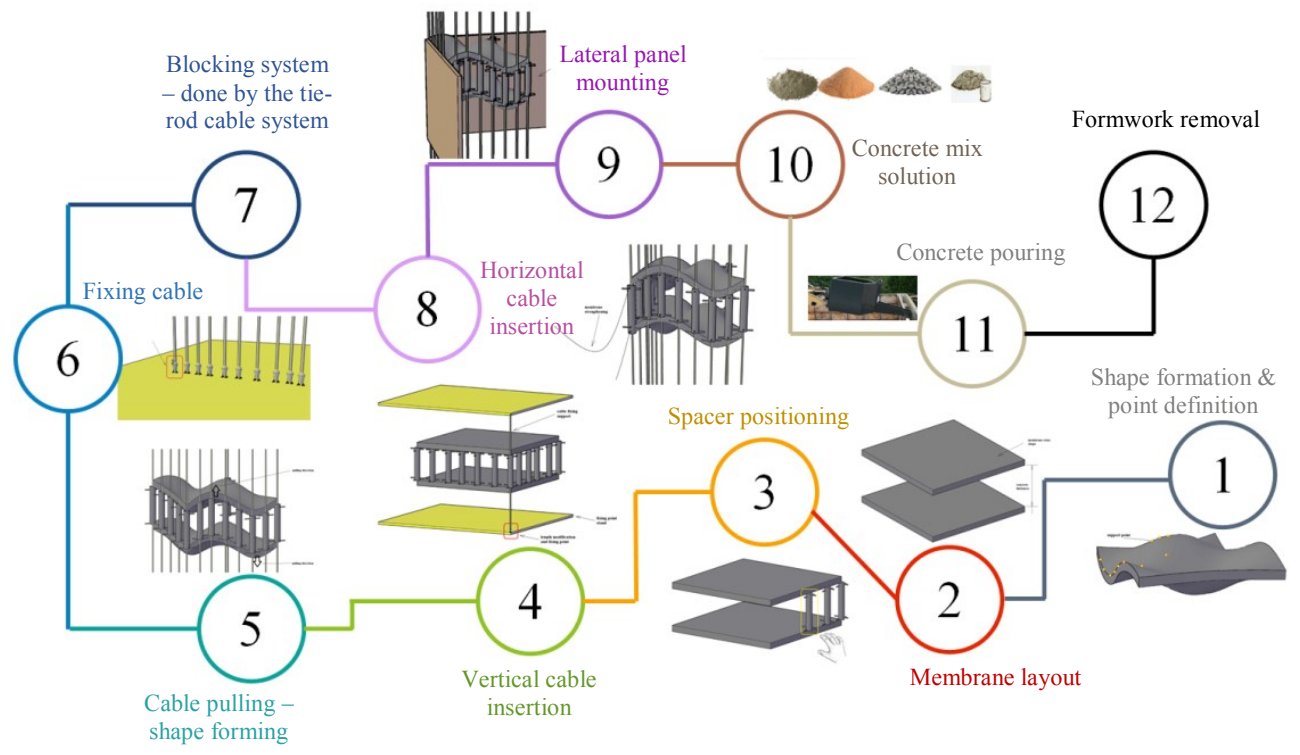

Fig. 11. Testing line membrane assembly and pouring steps

Note: The given shape is considered to be a free architectural shape for a roof. The final desired shape (Fig. 12) designed also in a CAD programme is of help in defining the points for the formwork. The control and fixing points of the nurb lines mark the spacer positioning. 


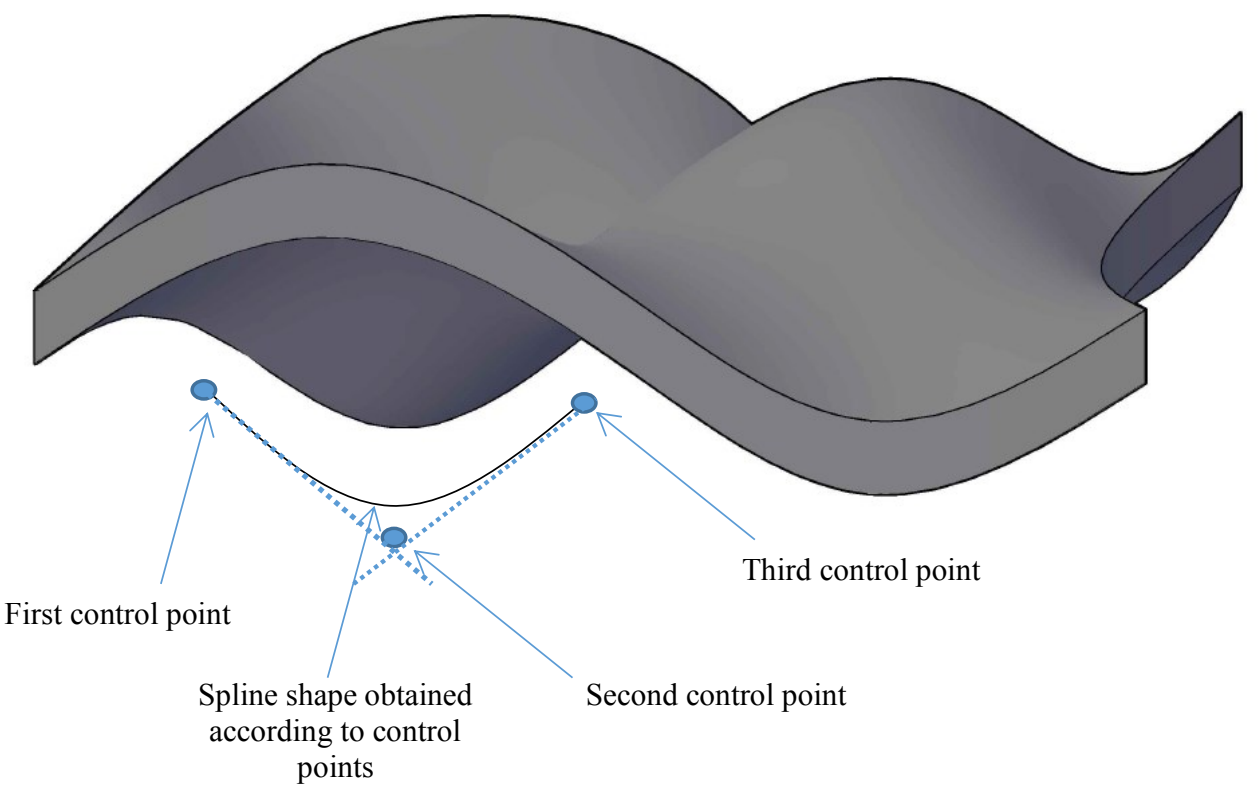

Fig. 12. Roof element (final/finite shape)

The same rubber types and thicknesses are used as previous tests [15]:

Table 3. Formwork material definition

\begin{tabular}{|c|c|c|}
\hline Type/ Name & $\begin{array}{c}\text { Thickness } \\
{[\mathbf{m m}]}\end{array}$ & $\begin{array}{c}\text { Specific weight } \\
{\left[\mathbf{g r} / \mathbf{c m}^{\mathbf{3}}\right]}\end{array}$ \\
\hline SBR & 1 & $1.7 \pm 0.05$ \\
\hline SBR & 2 & $1.7 \pm 0.05$ \\
\hline SBR & 3 & $1.7 \pm 0.05$ \\
\hline NBR & 1 & $1.5 \pm 0.05$ \\
\hline NBR & 2 & $1.5 \pm 0.05$ \\
\hline EPDM & 1 & $1.5 \pm 0.05$ \\
\hline
\end{tabular}

\section{Conclusions}

After a thorough research regarding demands, functions and multiple solution variants, the obtained constructive solution is an option to be put to test.

By using the PLM approach, we could reanalyse the problem, find new resources and establish a new constructive variant that serves all the new requirements for the personalised formwork.

By validating a new solution we can establish the area of workability, enlarge it and assess the sustainability of a new type of personalised formwork. 


\section{References}

1. T. Leslie, Laborious and Difficult: The Evolution of Pier Luigi Nervi's Hangar Roofs, 1935 (2018) DOI: 10.13140/RG.2.2.31482.39367

2. N. Janberg, Orbetello Hangars (2014) [https://structurae.net/structures/orbetello-hangars]. Access on January 2019

3. R.R.Royo, Club Táchira, 2016, [https://www.arquitecturayempresa.es/noticia/club-tachira-elencuentro-entre-la-idea-de-fruto-vivas-y-el-calculo-geometrico-de-eduardo]. Accessed on January 2019

4. K. Duque, Clásicos de Arquitectura: Club Táchira, 2014 [https://www.plataformaarquitectura.cl/cl/02-332131/ad-classics-club-tachira-fruto-vivaseduardo-torroja]. Accessed on January 2019

5. F. Escrig, J.Sanchez, Informes de la Construcción, The concrete vault of Club Táchira in Caracas, 57, 499-500 (2005) DOI: 10.3989/ic.2005.v57.i499-500.488

6. N. Janberg, Brühl Sports Center, 2014 [https://structurae.net/structures/bruhl-sports-center]. Access on January 2019

7. J.C Chilton, IASS, Potential unrealised? - The shells Heinz Isler might have built..(2010)

8. S. Makhno, 10 projects by Toyo Ito, 2016 [https://mahno.com.ua/en/blog/post/toyoito]. Access on January 2019

9. N. Mafi, The 12 Most Anticipated Buildings of 2018, 2017 [https://www.architecturaldigest.com/gallery/most-anticipated-buildings-of-2018]. Access on January 2019

10. Collins, 2019, [www.collinsdictionary.com]. Access on January 2019

11. A. Biswas, P. Agarwal, S. Purbita, D. Sayantan, P. Susmita, Shell structure, 2017, [https://www.slideshare.net/SusmitaPaul12/shell-structure]. Access on January 2019

12. A. Dogariu, Introduction to Shell Structures, [https://www.ct.upt.ro/suscos/files/20162018/L16_17_Shell\%20structures.pdf]. Access on January 2019

13. D. Dritschel, M. Lucia, A. Poje, PubMed, Ergodicity and spectral cascades in point vortex flows on the sphere (2015) DOI: 10.1103/PhysRevE.91.063014

14. D. Pender A model analysis of static stress in the vestibular membranes, Theoretical Biology and Medical Modelling, 6 (1), 19 (2009), DOI: 10.1186/1742-4682-6-19

15. R. Diaconu, Constructive varinats for personalised formwork, Acta Universitatis Cibiniensis 70(1), 73-80, (2018), DOI: 10.2478/aucts-2018-0010

16. H. Poggeler, A solid form for a difficult shell roof; Cement, 3, 139-145 (1982)

17. B. Kolarevic, Digital fabrication: Manufacturing architecture in the information age, In Proceedings of ACADIA, 13, 268-277 (2001)

18. S. Troian, S. Grünewald R. Schipper, E. Schlangen, O. Çopuroğlu, Deliberate Deformation of Concrete in the Fresh State-Crack Risk and Efficient Production of Curved Precast Elements, Springer International Publishing (2017), DOI: 10.1007/978-3-319-59471-2_287

19. H.R. Schipper, P. Eigenraam, Mapping double-curved surfaces for production of precast concrete shell elements, , Heron 61(3), 211-233 (2017)

20. Beton Ballon, 2014, Infl atable Mould [http://www.betonballon.nl/sites/default/fi les/dscf1943.jpg]. Accessed on February 2019

21. S. Boers, 2012, Fast and efficient fabrication with flexible Flexi Mold mold, [https://www.youtube.com/watch?v=Z-VLPO_o4I]. Accessed on February 2019

22. I. Rooy, P. Schinkel, 2009, Tensioned membrane, [http://www.bakdesign.net/ivo/Afstudeerverslag.pdf] . Accessed on February 2019

23. F. Huijben, 2014, Vacuumatics, [http://www.frankhuijben.nl/?page_id=305]. Accessed on February 2019 